C. A. Heywood, P. Bareka, Th. Karamplianis \& G. Kamari

\title{
Karyological study of miscellaneous Crocus (Iridaceae) species
}

\begin{abstract}
Heywood, C. A., Bareka, P., Karamplianis, Th. \& Kamari, G. 2017: Karyological study of miscellaneous Crocus (Iridaceae) species [In Kamari, G., Blanché, C. \& Siljak-Yakovlev, S. (eds), Mediterranean plant karyological data - 27]. - Fl. Medit. 27: 276-288. doi: 10.7320/FlMedit27.276

Chromosome numbers and karyotypes are given for the following species of Crocus: C. aleppicus, C. banaticus, C. boulosii, C. etruscus, C. gargaricus, C. herbertii, C. hermoneus, C. kosaninii, C. leichtlinii, C. longiflorus, C. moabiticus, C. scardicus, C. sieheanus, $C$. tommasinianus, $C$. veneris. Chromosome counts are also given for C. banaticus and C. longiflorus. Intraspecific variation was found in C. allepicus and C. hermoneus. Karyotype microphotographs or karyogram drawings are provided and karyotype morphology is discussed.
\end{abstract}

The genus Crocus is characterized by an enormous chromosomal variability. Some groups and species have proved particularly difficult taxonomically and have been found to contain chromosomal intraspecific variation. Although the chromosome number for several species mentioned in this study has been given in the past (Brighton \& al. 1973), the karyotype morphology for most of them was unknown until now.

1903. Crocus aleppicus Baker $-2 n=16$ (Figs $1 \mathrm{a}, 1 \mathrm{~b} \& 4 \mathrm{a})$.

Sy: Homs - Damascus, $34^{\circ} 06^{\prime} \mathrm{N}, 36^{\circ} 77^{\prime} \mathrm{E}$, Birkinshaw s.n., ref. no 73.2833 (K).

- Homs - Damascus, $33^{\circ} 84^{\prime}$ N, 36 $6^{\circ} 59^{\prime}$ E, Birkinshaw s.n., ref. no 70.1445 (K).

- W Dier Atiyah, Antilebanon, 34 09’ N, 36 76’ E, Barkoudah 162, ref. no 73.2967 (K). - Fig. $1 \mathrm{~b}$.

Le: 3 km S of Baalbek, $33^{\circ} 97^{\prime} \mathrm{N}, 36^{\circ} 19^{\prime} \mathrm{E}$, Marr 1677, ref. no 72.65 (K).

Feinbrun \& Shmida (1977) reported $2 n=16$ for $C$. aleppicus collected from Golan, Israel. We also found $2 n=16$ in this species and the four counts made extend the range as three were collected in Syria and one in Lebanon. Although all the plants examined had $2 n$ $=16$, one collection from Syria (73.2967) had a different karyotype morphology. Mathew (1982) states that plant material from its northern distribution (mainly Syria and partly Lebanon) holds blackish anthers. It is unknown if this karyotype from Syria (73.2967) is of atypical morphology; if so, then it suggests that this material might be of new infraspecific entity.

C. aleppicus is widespread in W Syria, through Lebanon to NE Israel and Jordan. It is an extremely variable species and further study might well discover further cytological 
variation. The most closely related species to $C$. aleppicus is $C$. veneris from Cyprus which has the same chromosome number and a similar seed surface (Mathew 1982).

$2 n=16$ A Cytotype. This comprised eight pairs of acrocentric chromosomes $(2 n=12 \mathrm{st}$ +4 st-SAT $=16)$, quite small in size, ranging between 2.34 to $5.00 \mu \mathrm{m}$. Small satellites were observed on the two smallest chromosome pairs (Figs 1a \& 4a).

$2 n=16 \mathrm{~B}$ Cytotype. The collection from Antilebanon (coll. Barkoudah 162) had slightly larger chromosomes and a karyotype consisting of one pair of metacentric chromosomes and seven arocentric pairs, ranging in size from 2.97 to $7.34 \mu \mathrm{m}$. The smallest chromosome pair has very small short arms subtending small satellites. Satellites were also observed on two other acrocentrics, also on the short arms (Fig. 1b). The karyotype formula is given as $2 n=2 \mathrm{~m}+8 \mathrm{st}+6 \mathrm{st}-\mathrm{SAT}=16$ chromosomes.

1904. Crocus banaticus J. Gay $-2 n=26$.

Rm: Sinaia, $45^{\circ} 33^{\prime}$ N, $25^{\circ} 55^{\prime}$ E, Barret s.n., ref. no 70.139 (K).

- Hunedoara, $45^{\circ} 75^{\prime} \mathrm{N}, 22^{\circ} 90^{\prime} \mathrm{E}$, Prasil KP42/72, ref. no 70.1391 (K).

- Hateg, $45^{\circ} 61^{\prime} \mathrm{N}, 22^{\circ} 95^{\prime} \mathrm{E}$, Prasil KP22/72, ref. no $73.68(\mathrm{~K})$.

- South of Oradea, $46^{\circ} 93^{\prime}$ N, $21^{\circ} 91^{\prime}$ E, Prasil KP01/73, ref. no 76.252 (K).

Mathew (1982) formerly placed C. banaticus in the subgenus Crociris B. Mathew, in contrast, Petersen \& al. (2008) in their phylogenetic study reported that Crocuses are of monophyletic origin; therefore the genus lacks any subgeneric division. It differs from other species in three ways; the style is branched into many slender lilac branches, the anthers open introrsely and the inner perianth segments are very much smaller than the outer ones. Because of this it is also been known as C. iridiflorus Heuff. ex Rchb. under which name it was chromosome counted by Heitz (1926), who reported $2 n=24-26$ chromosomes, while Mather (1932) recorded $2 n=26$. Karasawa $(1943,1950)$ reported $2 n=9$ for $C$. banaticus, but this must have been wrongly identified material.

In this study four collections from Romania were examined and all had $2 n=26$. The chromosomes were small with indistinct centromeres and a detailed analysis was not possible. However, it could be seen that one pair of acrocentric chromosomes has large satellites.

1905. Crocus baytopiorum B. Mathew $-2 n=28$ (Fig. 1c).

Tu: Honaz Dağ, $37^{\circ} 68^{\prime} \mathrm{N}, 29^{\circ} 30^{\prime} \mathrm{E}$, Baytop ISTE23.781, ref. no 73.2971 (K).

- Honaz Dağ, $37^{\circ} 71^{\prime}$ N, 29 236' E, Baytop ISTE23.781, ref. no 73.2811 (K).

- Honaz Dağ, $37^{\circ} 73^{\prime}$ N, 293 34' E, Mathew 8262, ref. no 76.234 (K).

This species from Turkey has no close relatives, although in some characters it resembles the C. vernus group (Mathew 1982). Mathew (2002) states that the taxon should be treated as a member of its own new series which he named series Baytopi B. Mathew (Mathew \& al. 2009). Additionally, phylogenetic studies of Petersen \& al. (2008) and Harpke \& al. (2013) supported excluding the taxon from series Verni B. Mathew. 


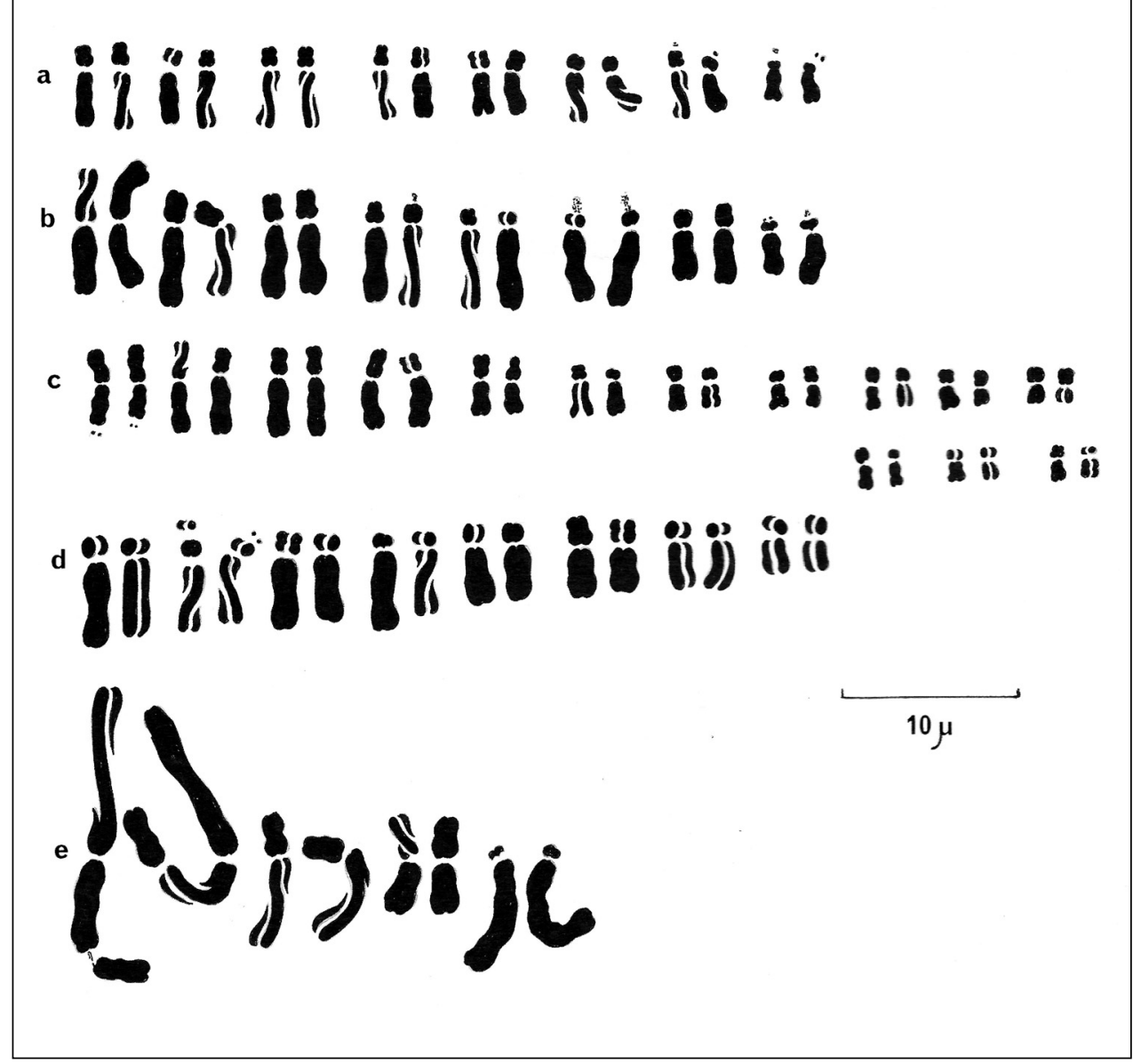

Fig. 1. Karyograms of Crocus species: a, C. aleppicus (ref. no 71.2333), $2 n=16 \mathrm{~A} ; \mathbf{b}$, C. aleppicus (ref. no 73.2967), $2 n=16 \mathrm{~A} ; \mathbf{c}$, C. baytopiorum (ref. no 76.234), $2 n=28 ; \mathbf{d}, C$. boulosii (ref. no 80.38 ), $2 n=16$; e, C. etruscus (ref. no 77.182), $2 n=8$ chromosomes.

Three collections were examined cytologically and they all came from Honaz Dağ in Turkey. They had $2 n=28$ and a karyotype consisting of small chromosomes, varying in size between 1.72 and $4.22 \mu \mathrm{m}$; one pair of metacentrics with small satellites, four pairs of sub-medians and nine pairs of acrocentric grading down in size (Fig. 1c). There was no obvious link with the $C$. vernus aggregate.

1906. Crocus boulosii Greuter $-2 n=16$ (Fig. 1d).

Li: Marawah, E of Benghazi, $32^{\circ} 48^{\prime} \mathrm{N}, 21^{\circ} 40^{\prime}$ E, Koenen \& Sarnetzki s.n., ref. no $80.38(\mathrm{~K})$. 
A rare Crocus from Libya is $C$. boulosii, whose closest affinities lie with C. aleppicus from the E Mediterranean mainland and with $C$. veneris Tapp. ex Poech from Cyprus. Although all three have the same chromosome number $2 n=16$, there is no obvious link karyologically. The sixteen chromosomes of $C$. boulosii are all acrocentric grading only slightly down in size $(3.12-6.25 \mu \mathrm{m})$. Quite small satellites were present on the short arms of the second pair (Fig. 1d).

1907. Crocus etruscus Parl. $-2 n=8$ (Figs 1e \& 4b).

It: Montieri near Massa Maritima, alt. $2400 \mathrm{~m}, 43^{\circ} 13^{\prime} \mathrm{N}, 11^{\circ} 02^{\prime} \mathrm{E}$, Marr 1870, ref. no $69.1188(\mathrm{~K})$.

- North Massa Maritima, road to Niccioleta, $43^{\circ} 06^{\prime} \mathrm{N}, 10^{\circ} 90^{\prime} \mathrm{E}$, Marr 1860, ref. no $77.182(\mathrm{~K})$.

Karasawa $(1937,1943)$ and Brandizzi \& al. (1996) reported $2 n=8$ for this species, while Mather (1932) reported $2 n=11$. The latter is thought to be a cultivar. Moreover, Baldini (1990) gave also the somatic number and the karyotype of this species. Indeed, $C$. etruscus, is an Italian species, with $2 n=8$ large chromosomes and a very distinctive karyotype. This comprises one pair of large metacentrics with a secondary constriction interstitially situated along one of the arms; one pair of sub-medians, a small pair of metacentrics and one pair of acrocentrics with very small short arms (Fig. 1e). The karyotype formula is slightly different from the one given by Baldini (l.c.) and is given as $2 n=4 \mathrm{~m}+$ $2 \mathrm{sm}+2 \mathrm{st}=8$ since there were no $\mathrm{M}$ chromosomes or microsatellites observed in the populations studied here. The chromosomes are ranging in size from 7.66 to $18.75 \mu \mathrm{m}$. The large metacentrics and acrocentrics make excellent marker chromosomes and because of this, it has been possible to consider that C. vernus (L.) Hill subsp. vernus $2 n=16$ (as $C$. napolitanus Mord. Laun.; Brighton 1976), which refers to the newly described C. neglectus Peruzzi \& Carta, is an allo-tetraploid (Frello \& Heslop-Harrison 2000) formed from an hybrid between $C$. etruscus and $C$. vernus subsp. vernus with $2 n=8$. This is further supported by phenotypic characters and geographical distribution. Harpke $\&$ al. (2015) reports that the maternal origin of the $C$. neglectus is $C$. ilvensis, both taxa shared $n h d \mathrm{~F}$ haplotype, and is parapatric only with C. etruscus.

It is thought that allo-polyploidy occurs elsewhere in the genus but it is not easy to discover it without clear marker chromosomes in the progenitors and only with classical karyological research.

1908. Crocus gargaricus Herb. $-2 n=30$ (Figs $2 b$ \& $4 c)$.

Tu: Muğla - Göktepe, $37^{\circ} 31^{\prime}$ N, $28^{\circ} 50^{\prime}$ E, Baytop s.n., ref. no 81.62 (K).

The preparations of $C$. gargaricus were made using $2 \%$ aceto-orcein stain in addition to the Feulgen and this may be why the chromosomes in this collection are slightly larger $(1.34-5.94 \mu \mathrm{m})$. Once again it had $2 n=30$ but the small satellites on the long arms of the 


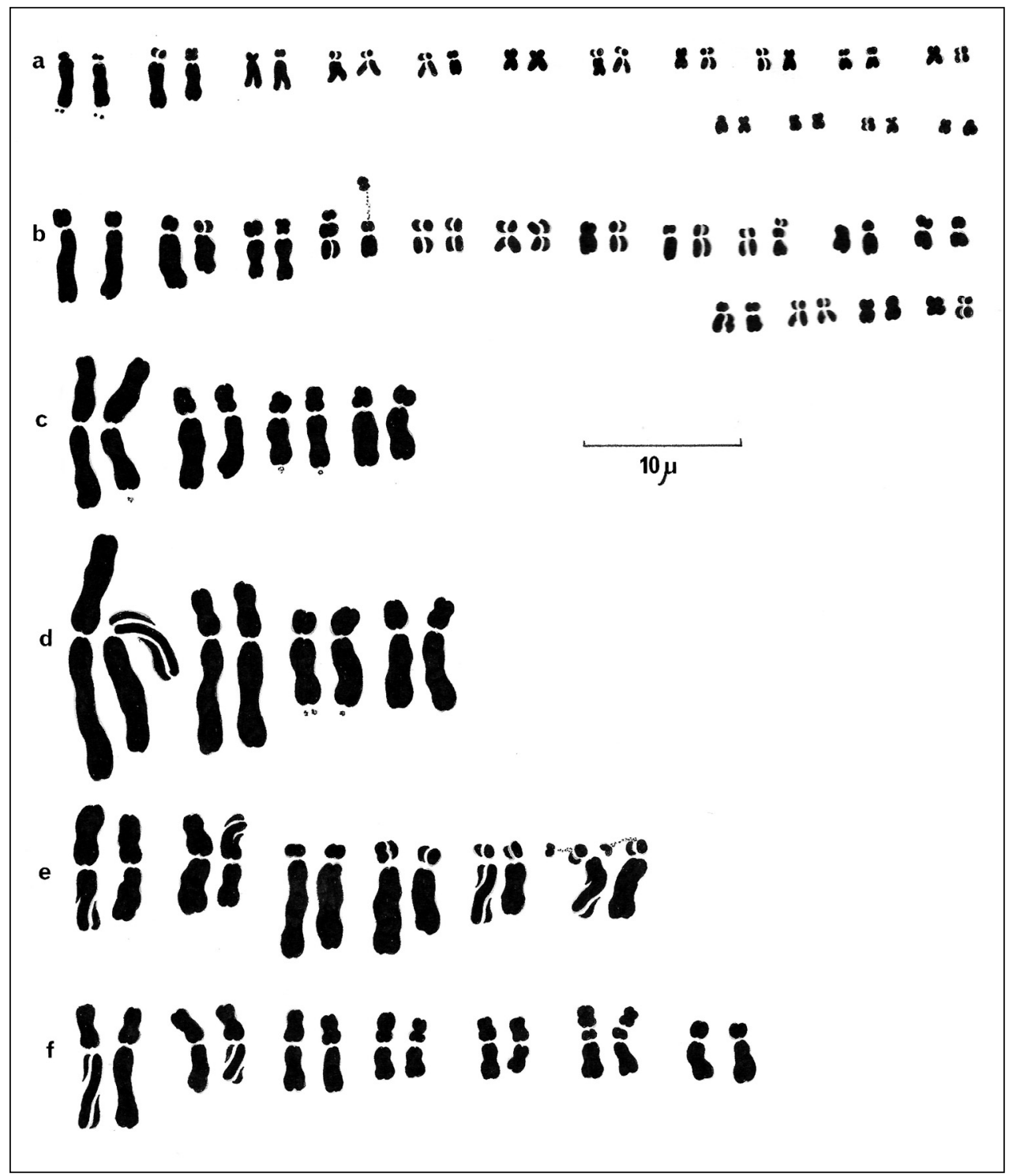

Fig. 2. Karyograms of Crocus species: a, C. herbertii (ref. no 76.381), $2 n=30 ; \mathbf{b}$, C. gargaricus (ref. no 81.62), $2 n=30$; c, $C$. hermoneus (ref. no 80.230), $2 n=8 ; \mathbf{d}$, C. hermoneus (ref. no 80.228), $2 n=8$; e, C. hermoneus (ref. no 70.203), $2 n=12$; f, C. kosaninii (ref. no 78.47), $2 n=$ 14 chromosomes.

large acrocentrics were not visible, and large satellites could be clearly seen on one pair of small submedians plus one other small submedian (Figs $2 b \& 4 c$ ). These satellites were large enough to be regarded as secondary constrictions occurring interstitially. 
1909. Crocus herbertii (B. Mathew) B. Mathew $-2 n=30$ (Fig. 2a).

Tu: Ulu Dağ, $40^{\circ} 07^{\prime}$ N, $29^{\circ} 22^{\prime}$ E, Marr 2216, ref. no 70.1516 (K).

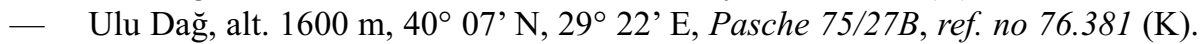

Mathew (1984) divided C. gargaricus into two subspecies; subsp. gargaricus and subsp. herbertii. His taxonomic treatment was based on the presence of stoloniferous roots and fine-reticulate corm tunics in subsp. herbertii. Mathew \& al. (2009), in the light of phylogenetic evidence by Petersen $\&$ al. (2008), indicate that the taxon merits recognition at specific rank. In this present study, we opt in favour of $C$. herbertii over $C$. thirkeanus [a taxonomic entity "resurrected" by Rukšāns (2017) and followed by Govaerts \& Barker (2017)] even though the latter antedate's subsp. herbertii, as type material has not been traced (Mathew 1984). This species comes from Ulu Dağ in northwestern Turkey.

C. herbertii has very small chromosomes, ranging from 1.03 to $3.59 \mu \mathrm{m}$, and karyotype details were difficult, however it was possible to distinguish two pairs of larger acrocentrics with satellites on the long arms (Fig. 2a).

1910. Crocus hermoneus Kotschy ex Maw $-2 n=8,12$ (including subsp. hermoneus and subsp. palaestinus Feinbrun) (Figs 2c, 2d, 2e \& 5a).

Ir: NNE Majdal - Shams, 33 $26^{\prime}$ N, $35^{\circ} 77^{\prime}$ E, Avi Shmida s.n., ref. no 80.230 (K). $-2 n=12$. - Figs $2 \mathrm{c} \& 5 \mathrm{a}$.

- Jerusalem, $31^{\circ} 78^{\prime} \mathrm{N}, 35^{\circ} 20^{\prime}$ E, Awishai s.n., ref. no $70.203(\mathrm{~K}) .-2 n=12$. - Fig. $2 \mathrm{e}$.

Jo: Salt Arda road to Ghor, $32^{\circ} 07^{\prime}$ N, $35^{\circ} 70^{\prime}$ E, Al-Eisawi s.n., ref. no 80.228 (K). $-2 n=8$. - Fig. 2 d.

- Amman, Umm Uthainah, $31^{\circ} 97^{\prime}$ N, 35 $87^{\circ}$ E, Al-Eisawi s.n., ref. no 80.229 (K). $-2 n=8$.

Feinbrun (1958) reported $2 n=12$ for C. hermoneus and in 1977 (Feinbrun \& Shmida 1977) she subdivided the species into subsp. hermoneus and subsp. palaestinus. She found $2 n=8$ in the former and $2 n=12$ in the latter. Material from Dr. Al-Eisawi from Salt and Amman in Jordan was assigned by Mathew (1982) to subsp. palaestinus but cytologically it corresponded with the subsp. hermoneus material of Avi Shmida from Israel, having $2 n$ $=8$ and a similar karyotype morphology.

C. hermoneus $2 n=8$ Cytotype: had a karyotype consisting of one pair of large metacentrics, one pair of large sub-medians and two pairs of smaller arocentrics one pair of which had small satellites on the long arms $(2 n=2 \mathrm{~m}+2 \mathrm{sm}+2 \mathrm{st}+2 \mathrm{st}-\mathrm{SAT}=8)$, ranging in size from 5.00 to $9.68 \mu \mathrm{m}$ (Figs $2 \mathrm{c}, 2 \mathrm{~d} \& 5 \mathrm{a}$ ). A small satellite was occasionally visible on one of the large metacentrics.

C. hermoneus $2 n=12$ Cytotype: had a karyotype consisting of two pairs of metacentrics and four pairs of acrocentrics with small short arms $(2 n=4 \mathrm{~m}+6 \mathrm{st}+2 \mathrm{st}-\mathrm{SAT}=8)$, which are smaller in size than those of $2 n=8$ Cytotype $(4.69-8.13 \mu \mathrm{m})$. One pair of acrocentrics had large satellites on the short arms (Fig. 2e). This corresponds with the findings of Feinbrun \& Shmida (1977). 


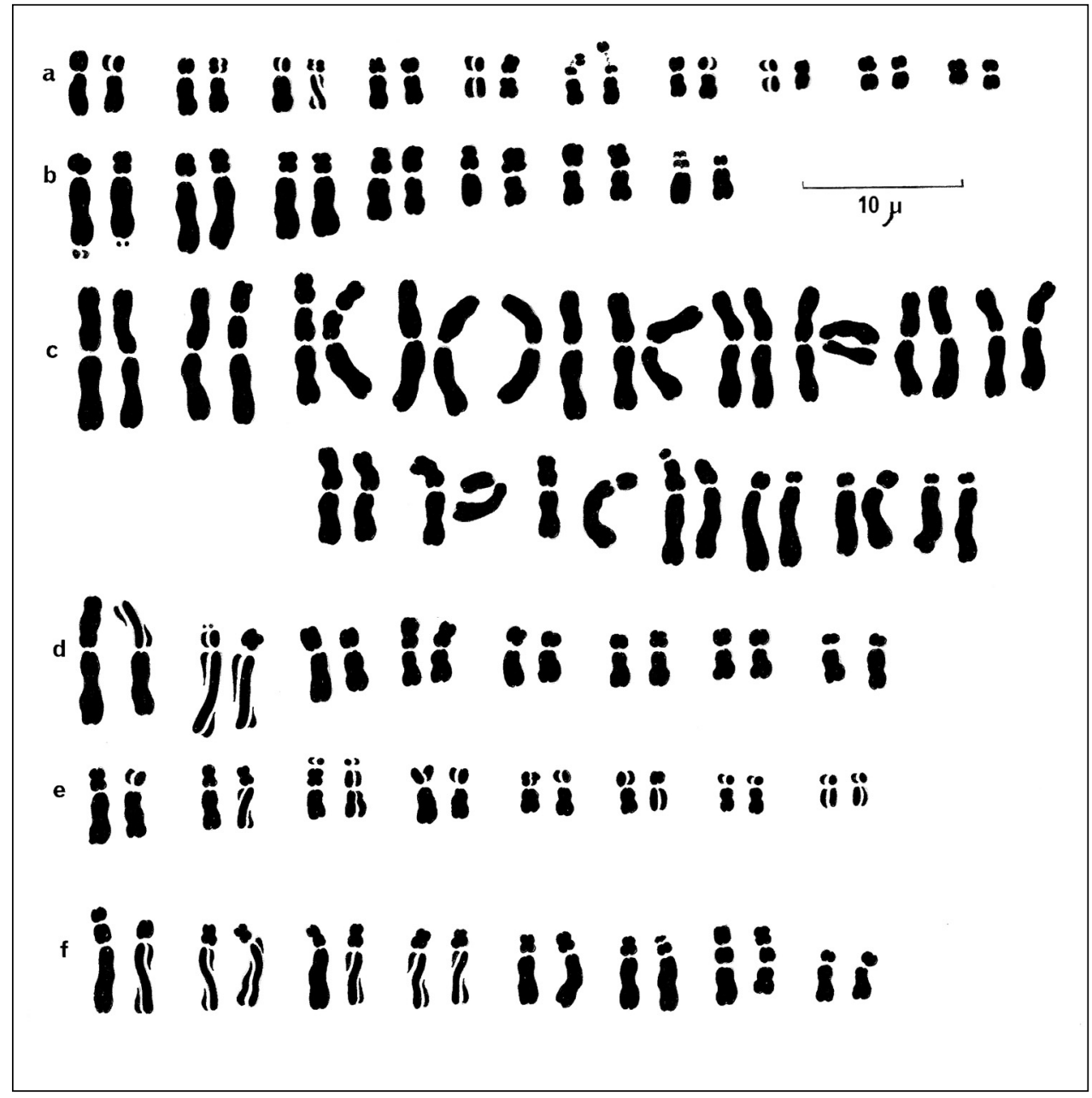

Fig. 3. Karyograms of Crocus species: a, C. leichtlinii (ref. no 77.28), $2 n=20 ; \mathbf{b}$, C. moabiticus (ref. no 80.233 ), $2 n=14$; c, C. scardicus (ref. no 80.243 ), $2 n=34$; d, C. sieheanus (ref. no 70.172), $2 n=16$; e, C. tommasinianus (ref. no 73.2897), $2 n=16$; f, C. veneris (ref. no 73.2969), $2 n=16$ chromosomes.

1911. Crocus kosaninii Pulevič $-2 n=14$ (Figs $2 \mathrm{f} \& 5 b$ ).

Sr: Kosovo near Kacanik, $42^{\circ} 23^{\prime} \mathrm{N}, 21^{\circ} 25^{\prime}$ E, Pulevič s.n., ref. no 78.47 (K).

- $13 \mathrm{~km} \mathrm{~N}$ of Kacanik, 42 $33^{\prime} \mathrm{N}, 2^{\circ} 20^{\prime} \mathrm{E}$, Crook 3007, ref. no 78.46 (K).

C. kosaninii is a relatively recently described species belonging to the $C$. vernus group (Mathew 1982; Harpke \& al. 2015). Both the number, $2 n=14$, and the karyotype are new to this group although the submedians with interstitial secondary constrictions are a feature 
of many members. C. kosaninii had a karyotype consisting of one large pair of submedians, five pairs of median-submedian chromosomes, one pair of which had secondary constrictions and one pair of acrocentrics. The chromosome size varies from 3.90 to $7.81 \mu \mathrm{m}$ (Figs $2 \mathrm{f} \& 5 b$ ).

1912. Crocus leichtlinii (Dewar) Bowles $-2 n=20$ (Figs $3 a \& 5 c$ ).

Tu: Karacadağ Urfa, alt. 1750 m, $37^{\circ} 73^{\prime}$ N, 39 $9^{\circ} 64^{\prime}$ E, Watson 1084 , ref. no 72.61 (K).

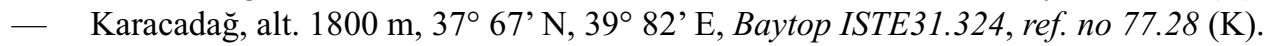

Mather (1932) reported $2 n=20$ for this species and our results confirm this. $C$. leichtlinii comes from Karacadağ in south-eastern Turkey. Both collections had $2 n=20$ small chromosomes $(1.83-4.33 \mu \mathrm{m})$ and a karyotype consisting of four pairs of acrocentrics, one pair of medians, two pairs of acrocentrics with large satellites on the short arms and three pairs of small median chromosomes $(2 n=8 \mathrm{~m}+8 \mathrm{st}+4 \mathrm{st}-\mathrm{SAT}=20)$ (Figs $3 \mathrm{a} \& 5 \mathrm{c})$.

1913. Crocus longiflorus Raf. $-2 n=28$.

It: Italy, Marr 2592, ref. no 77.792 (K).

Si: Sicily, E side of Mt. Etna, $37^{\circ} 75^{\prime} \mathrm{N}, 1^{\circ} 06^{\prime}$ E, Marr 2702, ref. no 76.290 (K).

- Sicily, Mt. Etna road, $37^{\circ} 69^{\prime} \mathrm{N}, 15^{\circ} 03^{\prime} \mathrm{E}$, Marr 2568A, ref. no 79.714 (K).

- Sicily, E side of Mt. Etna, $37^{\circ} 75^{\prime}$ N, $15^{\circ} 06^{\prime}$ E, Marr 2702, ref. no 76.290 (K).

- Malta, Verdala heights, $35^{\circ} 86^{\prime} \mathrm{N}, 14^{\circ} 40^{\prime} \mathrm{E}$, Saliba s.n., ref. no 72.185 (K).

- Malta, Verdala heights, $35^{\circ} 87^{\prime} \mathrm{N}, 14^{\circ} 39^{\prime}$ E, Saliba s.n., ref. no 74.1335 (K).

Mather (1932), Karasawa (1943) and Goldblatt \& Takei (1997) reported $2 n=28$ for this species and our results confirm this. Six collections from Sicily, Malta and Italy all had $2 n$ $=28$ small chromosomes; the karyotypes, however, were not clear enough to allow a more detailed analysis.

1914. Crocus moabiticus Bornm. \& Dinsm. ex Bornm. $-2 n=14$ (Fig. 3b).

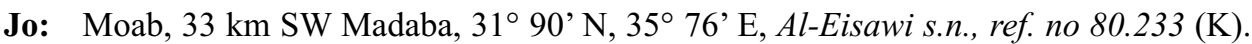

Mathew (1982) allies C. moabiticus to the Greek C. cartwrightianus $2 n=16$, but cytologically and geographically it is closer to $C$. pallasii subsp. dispathaceus with $2 n=14$ (Brighton 1977) and C. naqabensis with $2 n=14$ chromosomes (Al-Eisawi 2001). The collection examined came from Jordan and had a karyotype consisting of three pairs of acrocentrics with large satellites on the long arms of the first pair, three pairs of submedians and one pair of acrocentrics with small short arms subtending small satellites (Fig. 3b). The size of the chromosomes ranges from 2.83 to $6.17 \mu \mathrm{m}$. 


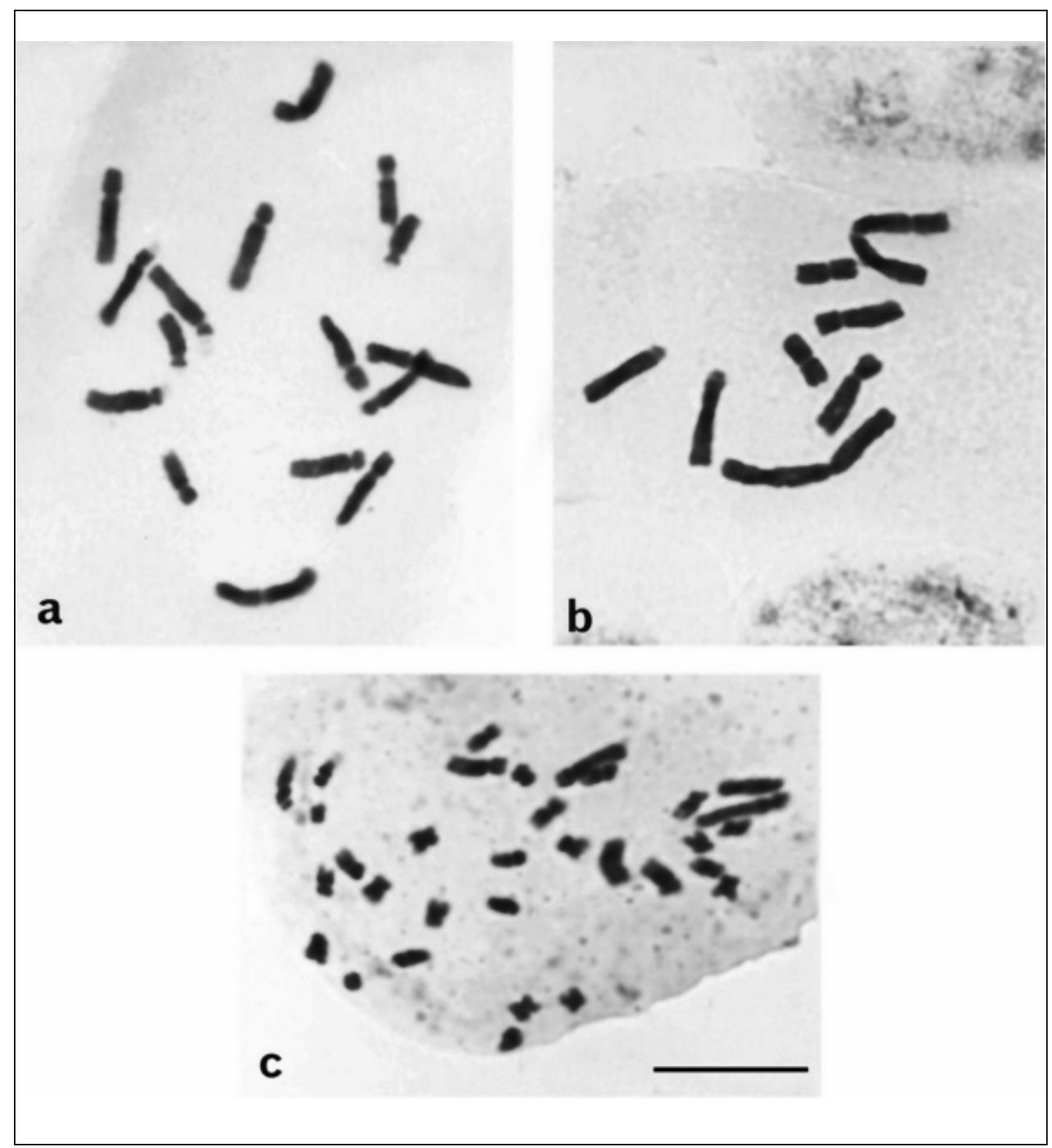

Fig. 4. Microphotographs of mitotic metaphase plates of Crocus species: a, C. aleppicus (ref. no 73.2967), $2 n=16$; b, C. etruscus (ref. no 69.1188), $2 n=8$; c, \& d, C. gargaricus (ref. no 81.62), $2 n$ $=30 .-$ Scale bar $=10 \mu \mathrm{m}$.

1915. Crocus scardicus Kosanin $-2 n=34$ (Figs $3 \mathrm{c} \& 5 \mathrm{~d})$.

Mk: F.Y.R.O.M., Sar Planina, $42^{\circ} 05^{\prime}$ N, $20^{\circ} 83^{\prime}$ E, Mathew 5254, ref. no 70.191 (K). $2 n=34$.

- F.Y.R.O.M., Tetovo, Popova Sapka, $42^{\circ} 01^{\prime}$ N, $20^{\circ} 87^{\prime}$ E, Archibald s.n., ref. no $80.243(\mathrm{~K}) .-2 n=34$. 
Both of the collections of $C$. scardicus examined here had $2 n=34$. The karyotype consisted of twelve pairs of metacentric chromosomes, one heteromorphic pair with a median and acrocentric chromosome, one pair of acrocentrics with a satellite on one chromosome, on the short arm and three pairs of acrocentrics with small short arms. Interstitial secondary constrictions could be seen in at least three of the metacentrics. The chromosome size ranges from 5.08 to $9.02 \mu \mathrm{m}$. The chromosomes did not readily fall into sets of four although they did fall in to sets of three $(3 \mathrm{x}=33+1)$ (Figs $3 \mathrm{c} \& 5 \mathrm{~d})$, and while being very similar to those of $C$. pelistericus $2 n=34$ there were some differences in karyotype morphology. Šopova (1972) reported counts of $2 n=32,34,35 \& 36$. She considered it to be a tetraploid with a tendency towards reduction. Obviously meiotic studies are needed in this case, and it would be interesting to do geimsa or other techniques on these two species.

C. scardicus and C. pelistericus are the only Crocus species which do not have a pale stripe on the upper surface of the leaf. Both species are distinct and very localized in their distribution.

1916. Crocus sieheanus B. L. Burtt $-2 n=16$ (Figs $3 \mathrm{~d} \& 5 \mathrm{e}$ ).

Tu: Niğde, $37^{\circ} 99^{\prime} \mathrm{N}, 34^{\circ} 68^{\prime} \mathrm{E}$, Mathew 4085, ref. no 69.1140 (K).

- Pozanti, $37^{\circ} 43^{\prime} \mathrm{N}, 34^{\circ} 88^{\prime} \mathrm{E}$, Mathew 4486B, ref. no 70.172 (K).

C. sieheanus is a distinct species from southern-central Turkey. Karasawa (1943) reported $2 n=16$ for this species and both our collections have the same number. The karyotype consisted of one pair of large metacentric, one pair of large acrocentric with satellites on the short arms, five pairs of acrocentric and one smaller pair of metacentric varying in size from 3.17 to $8.33 \mu \mathrm{m}$ (Figs $3 \mathrm{~d} \& 5 \mathrm{e}$ ).

1917. Crocus tommasinianus Herb. $-2 n=16$ (Fig. 3e).

Cg: Crmnica, $42^{\circ} 41^{\prime} \mathrm{N}, 19^{\circ} 05^{\prime}$ E, Lovka s.n., ref. no $73.3008(\mathrm{~K})$.

- Mt. Lovcen, $42^{\circ} 40^{\prime} \mathrm{N}, 18^{\circ}$ 82' E, Mathew 7528, ref. no 73.2897 (K).

- Mt. Orjen, $42^{\circ} 60^{\prime} \mathrm{N}, 18^{\circ} 54^{\prime} \mathrm{E}$, Mathew 5298, ref. no 70.212 (K).

- Mt. Orjen, $42^{\circ} 60^{\prime} \mathrm{N}, 18^{\circ} 55^{\prime} \mathrm{E}$, Mathew 5280, ref. no 70.165 (K).

- Mt. Orjen, $42^{\circ} 60^{\prime} \mathrm{N}, 18^{\circ} 54^{\prime} \mathrm{E}$, Mathew 5288, ref. no 69.1141 (K).

Mather (1932), Brittingham (1934), Pathaak (1940), Karasawa (1943) and Sušnik \& Lovka (1973) all reported $2 n=16$ for this species, and our results confirm this. Five collections all had the same karyotype of small chromosomes $(2.17-4.83 \mu \mathrm{m})$, submedian to acrocentric with large satellites on one pair of submedians (Fig. 3e).

1918. Crocus veneris Tapp. ex Poech. $-2 n=16$ (Fig. 3f).

Cy: Kalogrea, $35^{\circ} 34^{\prime}$ N, $33^{\circ} 62^{\prime}$ E, Osorio-Tafall \& Seraphim 7856, ref. no 73.33 (K). - Kalogrea, $35^{\circ} 33^{\prime}$ N , 33 64' E, Osorio-Tafall \& Seraphim 8217, ref. no 73.2969 (K). 


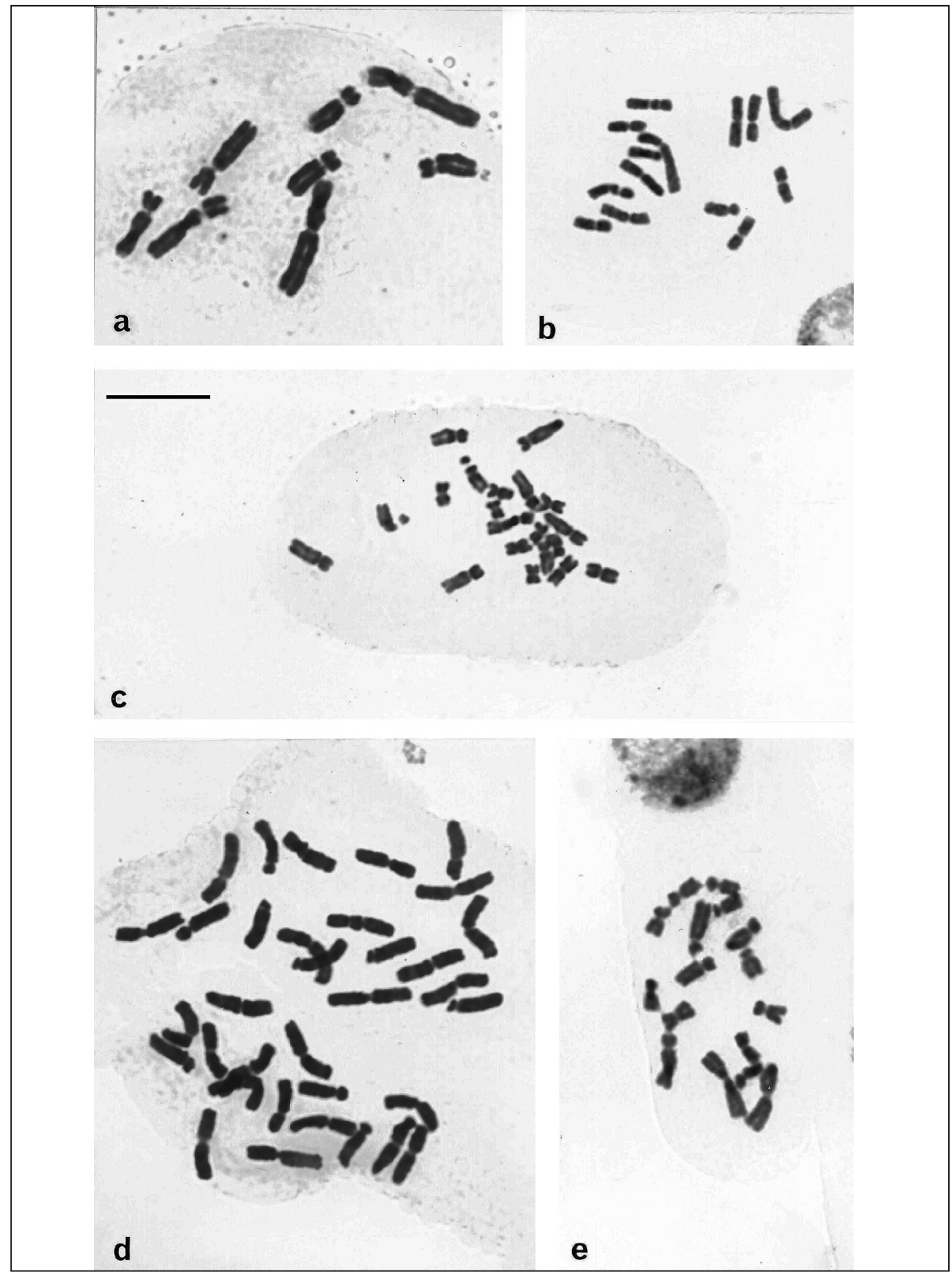

Fig. 5. Microphotographs of mitotic metaphase plates of Crocus species: a, C. hermoneus (ref. no 80.230 ), $2 n=8 ; \mathbf{b}, C$. kosaninii (ref. no 78.47), $2 n=14$; c, C. leichtlinii (ref. no 77.28), $2 n=$ 20; d, C. scardicus (ref. no 80.243), $2 n=34$; e, C. sieheanus (ref. no 69.1140), $2 n=16$. - Scale bar $=10 \mu \mathrm{m}$. 
- S of Agios Ambrosios, $35^{\circ} 32^{\prime}$ N, $33^{\circ} 58^{\prime}$ E, Osorio-Tafall \& Seraphim 8014, ref. no $73.2957(\mathrm{~K})$.

C. veneris is closely related to C. aleppicus, and like it has $2 n=16$ chromosomes but with a different karyotype, consisting of eight pairs of acrocentric chromosomes with one pair of satellites and a pair of proximal secondary constrictions in the long arms of another pair of chromosomes. The karyotype formula is given as $2 n=14 \mathrm{st}+2 \mathrm{st}-\mathrm{SAT}=16$ with chromosomes ranging in size from 3.33 to $6.00 \mu \mathrm{m}$ (Fig. 3f).

The chromosomes of Crocus continue to exhibit a bewildering array of variability, even within species and between subspecies. It is clearly a genus which merits a considerable amount of further research.

\section{References}

Al-Eisawi, D. 2001: Two new species of Iridaceae, Crocus naqabensis and Romulea petraea, from Jordan. - Arab Gulf J. Sci. Res. 19: 167-169.

Baldini, R. M. 1990: Caryological observations on two Crocus species (Iridaceae) from Tuscany (Italy). - Caryologia 43(3-4): 341-345.

Brandizzi, F. \& Grilli Caiola, M. 1997: Quantitative DNA analysis in different Crocus species (Iridaceae) by means of flow cytometry. - Giorn. Bot. Ital. 130(2): 643-645.

Brighton, C. A. 1976: Cytological problems in the genus Crocus (Iridaceae): 1. Crocus vernus aggregate. - Kew Bull. 31(1): 33-46.

- 1977: Cytology of Crocus sativus and its allies (Iridaceae). - Pl. Syst. Evol. 128: 137-157.

-, Mathew, B. \& Marchant, C. J. 1973: Chromosome counts in the genus Crocus. - Kew Bull. 28(3): 451-464.

Brittingham, W. H. 1934: Cytological studies on some genera of the Iridaceae. - Amer. J. Bot. 21: 77-82.

Feinbrun, N. 1958: Chromosome numbers in Crocus. - Genetica 29: 172-192.

— \& Shmida, A. 1977: A new review of the genus Crocus in Israel and neighboring countries. - Israel J. Bot. 26: 172-189.

Frello, S. \& Heslop-Harrison, J. S. 2000: Chromosomal Variation in Crocus vernus Hill (Iridaceae) Investigated by in situ Hybridization of rDNA and a Tandemly Repeated Sequence. - Ann. Bot. (London) 86: 317-322.

Goldblatt, P. \& Takei, M. 1997: Chromosome cytology of Iridaceae - patterns of variation, determination of ancestral base numbers, and modes of karyotype change. - Ann. Missouri Bot. Gard. 84: $285-304$.

Govaerts, R. \& Barker, C. 2017: World Checklist of Iridaceae. Facilitated by the Royal Botanic Gardens, Kew. Published on the Internet; http://wcsp.science.kew.org (Last Accessed: 14 October 2017).

Harpke, D., Meng, S., Rutten, T., Kerndorff, H. \& Blattner, F. R. 2013: Phylogeny of Crocus (Iridaceae) based on one chloroplast and two nuclear loci: Ancient hybridization and chromosome number evolution. - Mol. Phylogenet. Evol. 66: 617-627.

Carta, A., Tomović, G., Ranđelović, V., Ranđelović, N., Blattner, F. \& Peruzzi, L. 2015: Phylogeny, karyotype evolution and taxonomy of Crocus series Verni (Iridaceae). - Pl. Syst. Evol. 301: 309-325.

Heitz, E. 1926: Der Nachweis der Chromosomen. - Zeit. F. Bot. 18: 625-681. 
Karasawa, K. 1937: Karyological studies in Crocus L. - Jap. J. Bot. 9: 1-15.

- 1943: Karyological studies in Crocus L. - Jap. J. Bot. 12: 475-503.

- 1950: Note on the cytology of Crocus. - Genetica 25: 188-192.

Mather, K. 1932: Chromosome variation in Crocus 1. - J. Gent. 26: 129-142.

Mathew, B. F. 1982: The Crocus. A revision of the genus Crocus (Iridaceae). - London.

- 1984: Rare and little-known Crocuses in cultivation. - Kew Mag. 1(2): 72.

— 2002: Crocus up-date. The Plantsman, n.s., 1(1): 44-56.

—, Petersen, G. \& Seberg, O. 2009: A reassessment of Crocus based on molecular analysis. The Plantsman, n.s., 8: 50-57.

Pathak, G. N. 1940: Studies in cytology of Crocus. - Ann. Bot. 4: 227-256.

Petersen, G., Seberg, O., Thorsøe, S., Jørgensen, T. \& Mathew, B. 2008: A phylogeny of the genus Crocus (Iridaceae) based on sequence data from five plastid regions. - Taxon 57: 487-499.

Šopova, M. 1972: The cytology of ten Crocus species from Macedonia. - God. Zborn. 24: 73.

Rukšāns, J. 2017: The World of Crocuses. - Riga.

Sušnik, F. \& Lovka, M. 1973: Reports. [In Löve, A. (ed.), IOPB Chromosome number reports XLI]. - Taxon 22: 462-463.

Addresses of the authors:

Heywood, Christine A. ${ }^{1}$, Bareka, Pepy ${ }^{2}$, Karamplianis, Theophanis ${ }^{3}$ \& Kamari, Georgia ${ }^{4}$,

${ }^{1}$ Wokingham, RG40 1TP, UK. E-mail: caheywood@btinternet.com

${ }^{2}$ Laboratory of Systematic Botany, Faculty of Crop Science, Agricultural University of Athens, Iera Odos 75, GR-11855 Athens, Greece. E-mail: bareka@aua.gr

${ }^{3}$ Department of Ecology \& Systematics, Faculty of Biology, National \&

Kapodistrian University of Athens, Panepistimiopolis, GR-157 03 Athens, Greece.

E-mail: theo_karamp@biol.uoa.gr

${ }^{4}$ Botanical Institute, Department of Biology, University of Patras, GR-26500

Patras, Greece. E-mail: kamari@upatras.gr 